\title{
RESPONS FISIOLOGI, PERTUMBUHAN, PRODUKSI DAN SERAPAN P BAWANG MERAH (Allium ascalonicum L.) TERHADAP PEMBERIAN TRICHOKOMPOS TANDAN KOSONG KELAPA SAWIT (TKKS) TERFORMULASI DAN PUPUK P DI LAHAN GAMBUT
}

(Physiologcal Responses, Growth, Production and P Uptake by Shallots (Allium ascalonicum L.) Against Application of Trichokompos Oil Palm Empty Fruit Bunch (PEFB) Formulated and P Fertilizer on Peatlands)

\author{
ZALDI ARMAN ${ }^{*}$, NELVIA ${ }^{2}$ DAN ARMAINI ${ }^{2}$ \\ ${ }^{1}$ Program Studi Ilmu Pertanian Fascasarjana Universitas Riau \\ 2 Universitas Riau Kampus Bina Widya Km. 12,5 Simpang Baru Pekanbaru (28293) \\ ${ }^{*}$ Penulis Korespondensi : email zaldi.a.tt@gmail.com
}

\begin{abstract}
The study aims to determine the effect of formulated PEFB trichokompos and $P$ fertilizers on growth, physiology, production and $P$ uptake of onion in peatlands. This research used experimental factorial randomized completely block design and three replications. Trichokompos PEFB formulated as the first factor is composed of four levels $\left(0,5,10\right.$ and 15 ton ha $\left.{ }^{-1}\right)$ and $P$ fertilizers as the second factor consists of four levels $\left(0,120,180\right.$ and $\left.240 \mathrm{~kg} \mathrm{ha}^{-1} \mathrm{P}_{2} \mathrm{O}_{5}\right)$. Parameters measured were chlorophyll content, photosynthesis rate, stomataH2Oconductivity, the concentration of $\mathrm{CO}_{2}$ in the cell, transpiration rate, plant height, number of tillers, number of tubers per hill, the diameter of the bulbs, fresh weight of tuber per hill, plant dry weight and $P$ uptake. The results showed trichokompos PEFB formulated 15 ton ha-1 can increase the response of onion production as tuber diameter and fresh weight per hill and $P$ uptake response respectively by $25.58 \%, 74.92 \%$ and $76.39 \%$. While the physiological responses seen to decrease thestomatal $\mathrm{H}_{2} \mathrm{O}$ conductivity and transpiration rate of respectively $21.43 \%$ and $28.79 \%$ compared with no PEFB formulatedtrichokompos. Provision of fertilizer $\mathrm{P} 120 \mathrm{P}_{2} \mathrm{O}_{5}$ ha $^{-1}$ can improve physiological responses such as $\mathrm{H}_{2} \mathrm{O}$ on stomatal conductivity, increased growth responses such as plant height, such as the production response tuber diameter and fresh weight per hill and $P$ uptake response respectively by $7.69 \%, 22.25 \%, 26.23 \%, 56.21 \%$ and 44.26\% compared with no fertilizer $P$. combination trichokompos PEFB formulated 15 ton ha ${ }^{-1}$ with manure $P 120 \mathrm{P}_{2} \mathrm{O}_{5} \mathrm{ha}^{-1}$ is the best treatment combination, with the highest production response namely $7.65 \mathrm{~g}\left(1.91\right.$ ton $\left.\mathrm{ha}^{-1}\right)$ fresh weight per hill and increased $214.81 \%$ compared with no treatment trichokompos PEFB formulated and fertilizer $P$.
\end{abstract}

Keywords: Response of Shallots (Allium ascalonicum L.), Trichokompos PEFB formulated, phosphate fertilizer and peat

\section{PENDAHULUAN}

Bawang merah (Allium ascalonicum L.) merupakan salah satu tanaman hortikultura yang bernilai ekonomis tinggi dan kebutuhannya selalu meningkat. Produksi bawang merah di Riau masih rendah yaitu 12 ton tahun ${ }^{-1}$ (BPS Provinsi Riau, 2013). Hal ini disebabkan kurangnya pengetahuan petani tentang teknik budidaya terutama di lahan gambut, padahal Provinsi Riau berpotensi untuk pengembangan bawang merah karena memiliki lahan gambut mencapai $\pm 50 \%$ dari luas daratannya, yaitu 3.867 .413 ha (BBPPSLP, 2011).

Tanah gambut memiliki sifat fisik yang baik untuk pertumbuhan dan perkembangan umbi bawang merah, namun sifat kimianya merupakan kendala. Kendala sifat kimia gambut adalah $\mathrm{pH}$, kejenuhan basa, hara makro dan mikro rendah terutama hara $\mathrm{P}$
(Sasli, 2011), adanya asam-asam fenolat yang meracun bagi tanaman yang berasal dari biodegradasi senyawa lignin (Tan, 1986). Kehilangan air pada gambut di musim kemarau sangat cepat, sehingga perlu upaya pemberian trichokompos tandan kosong kelapa sawit (TKKS) terformulasi dan pupuk $\mathrm{P}$ sebagai sumber hara.

Trichokompos TKKS terformulasi adalah kompos TKKS yang didekomposisi dengan Trichoderma sp dan diperkaya dengan zeolit. Trichokompos TKKS terformulasi mengandung hara lengkap. Menurut Puspita (2014) $24,5 \%$ C-organik, 2,10\% N, 11,7 C/N, $2,16 \% \mathrm{P}_{2} \mathrm{O}_{5}, 2,49 \% \mathrm{~K}, 0,55 \% \mathrm{Mg}$ dan $0,99 \%$ $\mathrm{Ca}, 6,8 \mathrm{pH}$, dan 48,6 \% kadar air. Hasil penelitian Idwar et al. (2014) menunjukkan bahwa pemberian kompos TKKS $1,45 \mathrm{~kg}$ setiap 2,88 $\mathrm{m}^{2}$ (5 ton $\mathrm{ha}^{-1}$ ) di lahan gambut menunjukkan jumlah polong kedelai per tanaman paling tinggi yaitu 23,67 polong. 
Trichoderma sp sebagai dekomposer sehingga dapat mendekomposisi bahan organik di lahan gambut menjadi sempurna. Zeolit berperan meningkatkan kemampuan tanah menyerap air. Biyantoro et al. (2000) menyatakan zeolit dapat digunakan sebagai penyerap/adsorben, penukar kation dan mengkatalisasi suatu reaksi.

Hara $P$ sangat esensial peranannya terhadap pertumbuhan dan hasil tanaman. Menurut Havlin et al. (2005) P berperan dalam pembentukan inti sel, pembelahan dan perbanyakan sel, esensial pada proses fotosintesis dan metabolisme karbohidrat sebagai fungsi regulator pembagian hasil fotosintesis antara sumber dan organ reproduksi. Hasil penelitian Hamdani (2008) menunjukkan pemberian pupuk fosfat pada tanah ultisol sebanyak $180 \mathrm{~kg} \mathrm{P}_{2} \mathrm{O}_{5} \mathrm{ha}^{-1}$ dapat meningkatkan laju pertumbuhn relatif, bobot kering brangkasan, bobot umbi per rumpun (59,08 g rumpun $^{-1}$ atau 14,6 ton ha-1) dan memberikan indeks panen tertinggi pada tanaman bawang merah. Oleh sebab itu, dilakukan penelitian "respons fisiologi, pertumbuhan, produksi dan serapan $\mathrm{P}$ bawang merah (Allium ascalonicum L.) terhadap pemberian trichokompos TKKS terformulasi dan pupuk P di lahan gambut".

Penelitian bertujuan untuk mengetahui pengaruh pemberian trichokompos TKKS terformulasi dan pupuk $\mathrm{P}$ serta kombinasi keduanya terhadap respons fisiologi, pertumbuhan, produksi dan serapan $\mathrm{P}$ bawang merah di lahan gambut.

\section{BAHAN DAN METODE}

Penelitian dilakukan di lahan gambut kebun percobaan dan Laboratorium IImu Tanah Fakultas Pertanian Universitas Riau, mulai April sampai Juni 2015. Bahan yang digunakan : bibit umbi bawang merah varietas Bangkok, trichokompos TKKS terformulasi, pupuk TSP, urea, dan $\mathrm{KCl}$ (sumber $\mathrm{P}, \mathrm{N}$ dan K), Dithane $\mathrm{M}-45$ dan Sevin $85 \mathrm{~S}$. Alat yang digunakan : Chlorophyl meter, Portable Photosyntesis System LI-6400XT, AAS dan Spektrofotometer.

Penelitian dalam bentuk eksperimen dengan rancangan acak kelompok faktorial. Faktor pertama adalah Trichokompos TKKS terformulasi $\left(0,5,10\right.$ dan 15 ton ha $\left.{ }^{-1}\right)$ dan faktor kedua adalah pupuk $\mathrm{P}(0,120,180$ dan $240 \mathrm{~kg} \mathrm{P}_{2} \mathrm{O}_{5} \mathrm{ha}^{-1}$ ). Parameter yang diamati adalah responfisiologi yang meliputi kandungan klorofil, laju fotosintesis, daya hantar $\mathrm{H}_{2} \mathrm{O}$ pada stomata, konsentrasi $\mathrm{CO}_{2}$ dalam sel dan laju transpirasi. Respons pertumbuhan yang meliputi tinggi tanaman dan jumlah anakan. Respons produksi yang meiputi jumlah umbi per rumpun, diameter umbi, bobot segar umbi per rumpun dan bobot kering tanaman, serta respons serapan $P$. Data hasil pengamatan dianalisis secara statistik dengan analisis ragam dan dilanjutkan dengan uji jarak berganda Duncan $5 \%$.

\section{HASIL DAN PEMBAHASAN}

Tabel 1 menunjukkan bahwa reaksi tanah tergolong masam. Hal ini disebabkan gambut banyak mengandung asam organik, terutama gambut yang didominasi oleh kayu. Tsutsuki dan Kondo (1995) menyatakan dekomposisi kayu-kayuan yang kaya lignin dalam keadaan anaerob menghasilkan senyawa asam organik dan asam fenolat. Asam-asam organik selalu menyumbangkan ion $\mathrm{H}^{+}$. Menurut Noor (2001) ion $\mathrm{H}^{+}$pada asam-asam organik mudah terdisosiasi sehingga reaksi tanah menjadi masam.

Tabel 1. Sifat kimia tanah gambut lokasi penelitian

\begin{tabular}{|c|c|c|c|}
\hline Sifat kimia tanah & Satuan & Nilai & Kriteria \\
\hline $\mathrm{pH} \mathrm{H} \mathrm{H}_{2} \mathrm{O}$ & & 4,80 & Masam \\
\hline $\mathrm{pH} \mathrm{KCl}$ & & 3,92 & Sangat masam \\
\hline C organik & $\%$ & 28,07 & Sangat tinggi \\
\hline $\mathrm{N}$ total & $\%$ & 0,66 & Sedang \\
\hline $\mathrm{C} / \mathrm{N}$ & & 42,52 & Sangat tinggi \\
\hline $\mathrm{P}$ potensial $(\mathrm{HCl} 25 \%)$ & $\mu g g^{-1}(p p m)$ & 20,06 & Sedang \\
\hline $\mathrm{K}$ potensial ( $\mathrm{HCl} 25 \%)$ & $\mathrm{cmol}^{(+)} \mathrm{kg}^{-1}$ & 48,18 & Sangat tinggi \\
\hline $\mathrm{P}$ tersedia (P-Bray 1$)$ & $\mu g \mathrm{~g}^{-1}(\mathrm{ppm})$ & 8,77 & Rendah \\
\hline Ca-dd & $\mathrm{cmol}^{(+)} \mathrm{kg}^{-1}$ & 3,67 & Rendah \\
\hline K-dd & $\mathrm{cmol}^{(+)} \mathrm{kg}^{-1}$ & 0,20 & Rendah \\
\hline Mg-dd & $\mathrm{cmol}^{(+)} \mathrm{kg}^{-1}$ & 0,77 & Tinggi \\
\hline $\mathrm{Na}-\mathrm{dd}$ & $\mathrm{cmol}^{(+)} \mathrm{kg}^{-1}$ & 0,12 & Rendah \\
\hline KTK & $\mathrm{cmol}^{(+)} \mathrm{kg}^{-1}$ & 91,38 & Sangat tinggi \\
\hline Kejenuhan Basa (KB) & $\%$ & 5,21 & Sangat rendah \\
\hline
\end{tabular}

Kriteria : Pusat Penelitian Tanah (Laboratorium Tanah Bogor, 1983) 
Fosfor tersedia tergolong rendah karena $\mathrm{P}$ terikat lemah sehingga mudah tercuci. Fosfor tidak dapat terjerap pada koloid karena $\mathrm{P}$ dan koloid sama-sama bermuatan negatif. Menurut Stevenson (1994) sebagian besar $\mathrm{P}$ pada gambut dalam bentuk $\mathrm{P}$-organik, yang mengalami proses mineralisasi menjadi P-anorganik oleh jasad mikro. Yon (1994) menyatakan fosfor organik di dalam tanah terdapat sekitar $50 \%$ dari $\mathrm{P}$ total tanah dan bervariasi sekitar $15-80 \%$ pada kebanyakan tanah. Bentuk-bentuk fosfat ini berasal dari sisa tanaman, hewan dan mikroba. Fosfor dalam tanah yang diserap oleh tanaman sangat dipengaruhi oleh kondisi tanah, keadaan iklim dan kemampuan tanaman untuk menyerap hara dari tanah.

Kation basa seperti Ca-dd, K-dd dan Na-dd tergolong rendah rendah. Hal ini disebabkan senyawa asam organik sangat tinggi dan tinggi kapasitas tukar kation (KTK). Ratmini (2012) menyatakan asam-asam organik mengandung gugus karboksil dan fenolik, dimana gugus fungsi karboksil dan fenolik sebagai sumber muatan negatif. Tanah gambut dengan ciri KTK sangat tinggi, tetapi persentase KB sangat rendah, akan menyulitkan penyerapan hara, terutama basabasa yang diperlukan oleh tanaman.

\section{Respon Fisiologi Tanaman}

Tabel 2 menunjukkan bahwa kandungan klorofil, laju fotosintesis dan daya hantar $\mathrm{H}_{2} \mathrm{O}$ pada stomata tidak berbeda pada pemberian trichokompos TKKS terformulasi 5 hingga 15 ton ha-1 dan pupuk $\mathrm{P} 120$ hingga $240 \mathrm{~kg} \quad \mathrm{P}_{2} \mathrm{O}_{5} \quad \mathrm{ha}^{-1}$ serta kombinasi trichokompos TKKS terformulasi dengan pupuk $P$. Hal ini disebabkan $P$ tidak termasuk unsur yang berperan sebagai penyusun klorofil sehingga pemberian pupuk $P$ dan trichokompos TKKS terformulasi tidak berpengaruh terhadap kandungan klorofil. Hara yang berperan menyusun klorofil adalah Mg. Menurut Dwijoseputro (1980) bahwa faktor-faktor yang berpengaruh terhadap pembentukan klorofil adalah faktor pembawaan, cahaya, oksigen, karbohidrat, hara nitrogen, magnesium dan besi.

Tabel 2. Kandungan klorofil, laju fotosintesis, daya hantar $\mathrm{H}_{2} \mathrm{O}$ pada stomata, konsentrasi $\mathrm{CO}_{2}$ dalam sel dan laju transpirasi bawang merah pada pemberian trichokompos TKKS terformulasi dan pupuk $\mathrm{P}$

\begin{tabular}{|c|c|c|c|c|c|}
\hline \multirow{2}{*}{$\begin{array}{l}\text { Trichokompos } \\
\left(\text { ton } \mathrm{ha}^{-1}\right)\end{array}$} & \multicolumn{4}{|c|}{ Pupuk $\mathrm{P}\left(\mathrm{kg} \mathrm{P}_{2} \mathrm{O}_{5} \mathrm{ha}^{-1}\right)$} & \multirow{2}{*}{ Rata-rata } \\
\hline & 0 & 120 & 180 & 240 & \\
\hline \multicolumn{6}{|c|}{------ Kandungan klorofil $\left(\mu \mathrm{mol} \mathrm{m}^{-2}\right)$------ } \\
\hline 0 & $6,13^{a}$ & $5,38^{a}$ & $4,85^{\mathrm{a}}$ & $5,57^{a}$ & $5,48^{a}$ \\
\hline 5 & $5,93^{a}$ & $5,42^{\mathrm{a}}$ & $4,29^{a}$ & $4,61^{a}$ & $5,06^{a}$ \\
\hline 10 & $5,13^{\mathrm{a}}$ & $5,48^{\mathrm{a}}$ & $6,78^{\mathrm{a}}$ & $5,23^{a}$ & $5,65^{\mathrm{a}}$ \\
\hline 15 & $5,07^{a}$ & $5,82^{a}$ & $6,12^{\mathrm{a}}$ & $5,07^{a}$ & $5,52^{a}$ \\
\hline Rata-rata & $5,57^{a}$ & $5,52^{a}$ & $5,51^{a}$ & $5,12^{a}$ & \\
\hline \multicolumn{6}{|c|}{------- Laju fotosintesis $\left(\mu \mathrm{mol} \mathrm{CO} \mathrm{CO}^{-2} \mathrm{~s}^{-1}\right)$} \\
\hline 0 & $4,35^{\mathrm{a}}$ & $0,90^{\mathrm{a}}$ & $2,01^{a}$ & $9,75^{a}$ & $4,25^{\mathrm{a}}$ \\
\hline 5 & $0,36^{a}$ & $1,80^{a}$ & $0,99^{a}$ & $3,31^{a}$ & $1,62^{a}$ \\
\hline 10 & $1,26^{a}$ & $3,11^{a}$ & $8,66^{a}$ & $8,45^{a}$ & $5,37^{a}$ \\
\hline 15 & $2,75^{\mathrm{a}}$ & $14,78^{\mathrm{a}}$ & $0,28^{a}$ & $1,38^{a}$ & $4,80^{a}$ \\
\hline Rata-rata & $2,18^{a}$ & $5,15 a$ & $2,98^{a}$ & $5,72^{a}$ & \\
\hline \multicolumn{6}{|c|}{------- Daya hantar $\mathrm{H}_{2} \mathrm{O}$ pada stomata $\left(\mathrm{mol} \mathrm{H}_{2} \mathrm{O} \mathrm{m}^{-2} \mathrm{~s}^{-1}\right)$------ } \\
\hline 0 & $0,23^{a}$ & $0,16^{\mathrm{a}-\mathrm{d}}$ & $0,07^{\text {de }}$ & $0,08^{\mathrm{c}-\mathrm{e}}$ & $0,14^{\mathrm{a}}$ \\
\hline 5 & $0,04^{e}$ & $0,05^{\text {de }}$ & $0,10^{\mathrm{b}-\mathrm{e}}$ & $0,08^{\mathrm{c}-\mathrm{e}}$ & $0,07^{b}$ \\
\hline 10 & $0,07^{\text {de }}$ & $0,20^{\mathrm{ab}}$ & $0,11^{\mathrm{b}-\mathrm{e}}$ & $0,09^{\mathrm{c}-\mathrm{e}}$ & $0,12^{a}$ \\
\hline 15 & $0,19^{a-c}$ & $0,14^{\mathrm{a}-\mathrm{e}}$ & $0,06^{\mathrm{de}}$ & $0,04^{\mathrm{e}}$ & $0,11^{\mathrm{ab}}$ \\
\hline Rata-rata & $0,13^{\mathrm{a}}$ & $0,14^{\mathrm{a}}$ & $0,09^{\mathrm{ab}}$ & $0,07^{b}$ & \\
\hline \multicolumn{6}{|c|}{------- Konsentrasi $\mathrm{CO}_{2}$ dalam sel $\left(\mu \mathrm{mol} \mathrm{CO}_{2} \mathrm{~mol}^{-1}\right)$------- } \\
\hline 0 & $276,1^{\mathrm{a}}$ & $354,4^{a}$ & $405,9^{a}$ & $552,2^{\mathrm{a}}$ & $397,2^{a}$ \\
\hline 5 & $346,2^{\mathrm{a}}$ & $396,4^{\mathrm{a}}$ & $375,4^{\mathrm{a}}$ & $317,0^{\mathrm{a}}$ & $358,8^{a}$ \\
\hline 10 & $392,8^{a}$ & $339,1^{\mathrm{a}}$ & $227,1^{\mathrm{a}}$ & $458,7^{a}$ & $354,4^{\mathrm{a}}$ \\
\hline 15 & $351,8^{a}$ & $349,6^{a}$ & $367,9^{a}$ & $442,9^{a}$ & $378,0^{\mathrm{a}}$ \\
\hline Rata-rata & $341,7^{\mathrm{a}}$ & $359,9^{\mathrm{a}}$ & $344,1^{\mathrm{a}}$ & $442,7^{a}$ & \\
\hline \multicolumn{6}{|c|}{--- Laju transpirasi $\left(\mathrm{mmol} \mathrm{H}_{2} \mathrm{O} \mathrm{m}^{-2} \mathrm{~s}^{-1}\right)$} \\
\hline 0 & $4,66^{a}$ & $4,28^{a-c}$ & $1,98^{\mathrm{d}-\mathrm{f}}$ & $2,02^{c-f}$ & $3,23^{a}$ \\
\hline 5 & $1,06^{f}$ & $1,21^{\text {ef }}$ & $2,76^{\mathrm{a}-\mathrm{f}}$ & $1,77^{\mathrm{d}-\mathrm{f}}$ & $1,70^{\mathrm{b}}$ \\
\hline 10 & $2,14^{\mathrm{b}-\mathrm{f}}$ & $4,31^{\mathrm{ab}}$ & $3,46^{\mathrm{a}-\mathrm{e}}$ & $2,48^{a-f}$ & $3,10^{\mathrm{a}}$ \\
\hline 15 & $3,75^{a-d}$ & $2,67^{a-f}$ & $1,83^{\text {def }}$ & $0,94^{\dagger}$ & $2,30^{b}$ \\
\hline Rata-rata & $2,90^{a}$ & $3,12^{a}$ & $2,51^{\mathrm{ab}}$ & $1,80^{\mathrm{b}}$ & \\
\hline
\end{tabular}

Ket. Angka yang diikuti oleh huruf kecil yang sama pada setiap perlakuan utama dan kombinasinya, tidak berbeda nyata menurut uji jarak berganda Duncan $5 \%$ 
Kandungan klorofil dan konsentrasi $\mathrm{CO}_{2}$ yang tidak berbeda dapat menyebabkan laju fotosintesis juga tidak berbeda. Hal ini disebabkan klorofil sangat berperan pada proses fotosintesis. Menurut Lakitan (2011) salah satu yang berpengaruh terhadap laju fotosintesis adalah klorofil dan $\mathrm{CO}_{2}$. Laju fotosintesis dipengaruhi oleh serapan P. Nilai korelasi antara laju fotosintesis dengan serapan $P$ yaitu $r=0,585$. Fosfor sangat berperan pada proses fotosintesis, dimana proses fotosintesis membutuhkan energi dalam bentuk ATP. Hasil penelitian Singh dan Reddy (2014) kekurangan P secara konsisten dapat menurun fotosintesis.

Konsentrasi $\mathrm{CO}_{2}$ dalam sel dipegaruhi oleh daya hantar $\mathrm{H}_{2} \mathrm{O}$ pada stomata. Nilai korelasi konsentrasi $\mathrm{CO}_{2}$ dalam sel dengan daya hantar $\mathrm{H}_{2} \mathrm{O}$ pada stomata sebesar $\mathrm{r}=$ 0,640 . Sewaktu tanaman memfiksasi $\mathrm{CO}_{2}$ dari udara, tanaman mengeluarkan $\mathrm{H}_{2} \mathrm{O}$ sehingga peningkatan daya hantar $\mathrm{H}_{2} \mathrm{O}$ pada stomata dapat meningkatkan konsentrasi $\mathrm{CO}_{2}$ dalam sel. Menurut Von dan Farquhar (1981) molekul $\mathrm{H}_{2} \mathrm{O}$ yang berdifusi keluar dari stomata mempengaruhi masuknya molekul $\mathrm{CO}_{2}$.

Tabel 2 menunjukkan nilai daya hantar $\mathrm{H}_{2} \mathrm{O}$ pada stomata dan laju transpirasi pada pemberian trichokompos TKKS terformulasi 5 hingga 15 ton ha-1 dan pupuk $P 120$ hingga $240 \mathrm{~kg} \quad \mathrm{P}_{2} \mathrm{O}_{5} \quad \mathrm{ha}^{-1}$ serta kombinasi trichokompos TKKS terformulasi dengan pupuk P. Pemberian trichokompos TKKS terformulasi dan pupuk $\mathrm{P}$ terlihat bahwa nilai daya hantar $\mathrm{H}_{2} \mathrm{O}$ pada stomata paling tinggi yaitu $0,23 \mathrm{~mol} \mathrm{H}_{2} \mathrm{O} \mathrm{m}^{-2} \mathrm{~s}^{-1}$ dan cenderung meningkat dibandingkan kombinasi perlakuan lainnya. Peningkatan daya hantar $\mathrm{H}_{2} \mathrm{O}$ stomata pada tanpa pemberian trichokompos TKKS terformulasi dan pupuk $\mathrm{P}$ berkisar $15-475 \%$ dibandingkan kombinasi perlakuan lainnya. Hal ini diduga disebabkan tegangan turgor sel penutup stomata meningkat pada tanpa pemberian trichokompos TKKS terformulasi dan pupuk $\mathrm{P}$, sehingga menyebabkan stomata membuka. Membukanya stomata dapat meningkatkan daya hantar $\mathrm{H}_{2} \mathrm{O}$ pada stomata. Menurut Tjitrosomo (1984) stomata akan membuka apabila turgor sel penutup tinggi dan apabila turgor sel penutup rendah maka stomata akan menutup.

$$
\text { Kombinasi perlakuan tanpa }
$$

trichokompos TKKS terformulasi dan pupuk $\mathrm{P}$ terlihat bahwa laju transpirasi paling tinggi yaitu $4,66 \mathrm{mmol} \mathrm{H}_{2} \mathrm{O} \mathrm{m} \mathrm{m}^{-2} \mathrm{~s}^{-1}$ dan cenderung meningkat 8,12 - $339 \%$ dibandingkan kombinasi perlakuan lainnya. Hal ini disebabkan turgiditas sel pada stomata meningkat sehingga laju transpirasi dapat meningkat. Menurut Cambell et al. (2003) sel penutup mengontrol diameter stomata dengan cara mengubah bentuk yang akan melebarkan dan menyempitkan celah di antara kedua sel tersebut. Ketika sel penutup mengambil air melalui osmosis, sel penutup akan membengkak dan semakin dalam keadaan turgid. Perubahan tekanan turgor yang menyebabkan pembukaan dan penutupan stomata terutama disebabkan oleh pengambilan dan kehilangan ion Kalium secara reversibel oleh sel penutup.

\section{Respon Pertumbuhan}

Tabel 3 menunjukkan bahwa tinggi tanaman dan jumlah anakan tidak berbeda pada pemberian trichokompos TKKS terformulasi 5 hingga 15 ton ha ${ }^{-1}$ dan pupuk $\mathrm{P}$ 120 hingga $240 \mathrm{~kg} \mathrm{P}_{2} \mathrm{O}_{5}$ ha $^{-1}$ serta kombinasi trichokompos TKKS terformulasi dengan pupuk $P$, kecuali pemberian pupuk $P 120$ hingga $240 \mathrm{~kg} \mathrm{P}_{2} \mathrm{O}_{5} \mathrm{ha}^{-1}$ dapat meningkatkan tinggi tanaman. Hal ini disebabkan pertumbuhan tinggi tanaman dan jumlah anakan lebih dominan dipengaruhi oleh hara $\mathrm{N}$, sedangkan $\mathrm{N}$ pada tanah gambut tergolong sedang (Tabel 1) dan mudah tercuci akibat KTK tanah gambut tergolong sangat tinggi (Tabel 1) sehingga tidak tersedia bagi tanaman. Menurut Agus dan Subiksa (2008) KTK tinggi menunjukkan kapasitas jerapan (sorbtion capacity) gambut tinggi, namun kekuatan jerapan (sorbtion power) lemah, sehingga kation-kation yang tidak membentuk ikatan koordinasi akan mudah tercuci.

Hasil penelitian Jumini et al. (2010) menunjukkan tinggi tanaman bawang merah tidak berbeda nyata pada pemberian pupuk organik. Tinggi tanaman dapat dipengaruhi oleh meningkatnya laju fotosintesis. Nilai korelasi antara tinggi tanaman dengan laju fotosintesis adalah $r=0,569$. Laju fotosintesis yang meningkat dapat meningkatkan fotosintat yang dapat ditranslokasikan ke bagian batang daun sehingga tinggi tanaman meningkat. Hasil penelitian Saputro (2011) menunjukkan bahwa peningkatan laju fotosintesis tanaman kedelai sebesar $17,52 \%$, berdampak pada peningkatan produksi tanaman kedelai sebesar $40,68 \%$.

Pemberian pupuk $P 120$ hingga $240 \mathrm{~kg}$ $\mathrm{P}_{2} \mathrm{O}_{5}$ ha $^{-1}$ dapat meningkatkan tinggi tanaman. Peningkatan tinggi tanaman paling tinggi pada pemberian pupuk $\mathrm{P} 120 \mathrm{~kg}_{2} \mathrm{O}_{5} \mathrm{ha}^{-1}$ dan meningkat $22,25 \%$ dibanding tanpa pupuk $P$. Hal ini disebabkan $P$ berperan dalam pembelahan dan perbanyakan sel sehingga tinggi tanaman dapat meningkat. Fosfor juga berperan mendorong pertumbuhan akar tanaman sehingga meningkatkan penyerapan hara $\mathrm{P}$ pada tanaman. Peningkatan 
penyerapan $\mathrm{P}$ pada tanaman dapat meningkatkan pertumbuhan tinggi tanaman. Havlin et al. (2005) menyatakan $P$ berperan dalam pembetukan inti sel, pembelahan, perbanyakan sel sedangkam menurut Rosmarkam dan Yuwono, (2002) P dapat mendorong pertumbuhan akar tanaman.

Tabel 3. Tinggi tanaman dan jumlah anakan bawang merah pada pemberian trichokompos TKKS terformulasi dan pupuk $\mathrm{P}$

\begin{tabular}{|c|c|c|c|c|c|}
\hline \multirow{2}{*}{$\begin{array}{l}\text { Trichokompos } \\
\left.\text { (ton } \mathrm{ha}^{-1}\right)\end{array}$} & \multicolumn{4}{|c|}{ Pupuk $\mathrm{P}\left(\mathrm{kg} \mathrm{P}_{2} \mathrm{O}_{5} \mathrm{ha}^{-1}\right)$} & \multirow{2}{*}{ Rata-rata } \\
\hline & 0 & 120 & 180 & 240 & \\
\hline \multicolumn{6}{|c|}{---------- Tinggi tanaman (cm) ---------- } \\
\hline 0 & $18,78^{\mathrm{a}}$ & $19,34^{a}$ & $18,78^{\mathrm{a}}$ & $20,78^{a}$ & $19,42^{a}$ \\
\hline 5 & $16,78^{\mathrm{a}}$ & $21,78^{\mathrm{a}}$ & $22,67^{a}$ & $21,67^{a}$ & $20,72^{a}$ \\
\hline 10 & $17,89^{a}$ & $21,67^{a}$ & $21,89^{a}$ & $21,11^{\mathrm{a}}$ & $20,64^{\mathrm{a}}$ \\
\hline 15 & $19,00^{\mathrm{a}}$ & $25,77^{\mathrm{a}}$ & $22,44^{\mathrm{a}}$ & $20,34^{\mathrm{a}}$ & $21,89^{a}$ \\
\hline Rata-rata & $18,11^{\mathrm{b}}$ & $22,14^{\mathrm{a}}$ & $21,44^{\mathrm{a}}$ & $20,97^{a}$ & \\
\hline \multicolumn{6}{|c|}{-------------- Jumlah anakan (batang) ---------------- } \\
\hline 0 & $5,93^{a}$ & $7,27^{a}$ & $6,90^{a}$ & $9,12^{a}$ & $7,30^{a}$ \\
\hline 5 & $7,86^{\mathrm{a}}$ & $7,49^{a}$ & $7,38^{a}$ & $8,41^{a}$ & $7,78^{a}$ \\
\hline 10 & $7,38^{a}$ & $7,60^{\mathrm{a}}$ & $9,12^{\mathrm{a}}$ & $9,60^{\mathrm{a}}$ & $8,42^{a}$ \\
\hline 15 & $8,24^{a}$ & $7,46^{\mathrm{a}}$ & $7,12^{a}$ & $7,27^{a}$ & $7,52^{a}$ \\
\hline Rata-rata & $7,35^{a}$ & $7,45^{a}$ & $7,63^{a}$ & $8,60^{a}$ & \\
\hline
\end{tabular}

Ket : Angka yang diikuti oleh huruf kecil yang sama pada setiap perlakuan utama dan kombinasinya, tidak berbeda nyata menurut uji jarak berganda Duncan $5 \%$

\section{Respon Produksi}

Tabel 4 menunjukkan bahwa jumlah umbi per rumpun tidak berbeda pada pemberian trichokompos TKKS terformulasi 5 hingga 15 ton ha-1 dan pupuk $\mathrm{P} 120$ hingga $240 \mathrm{~kg} \quad \mathrm{P}_{2} \mathrm{O}_{5} \quad \mathrm{ha}^{-1}$ serta kombinasi trichokompos TKKS terformulasi dengan pupuk $P$. Hal ini diduga disebabkan jumlah umbi per rumpun lebih dominan dipengaruhi oleh faktor genetik. Menurut Gardner et al. (1991) salah satu faktor yang mempengaruhi pertumbuhan tanaman adalah faktor genetik. Jumlah umbi per rumpun dapat dipengaruhi oleh jumlah anakan per rumpun. Nilai korelasi antara jumlah umbi per rumpun dengan jumlah anakan sebesar $r=1,00$, sehingga peningkatan jumlah anakan mempengaruhi meningkatnya jumlah umbi per rumpun.

Tabel 4. Jumlah umbi per rumpun, diameter umbi, bobot segar umbi per rumpun dan bobot kering tanaman bawang merah pada pemberian trichokompos TKKS terformulasi dan pupuk $\mathrm{P}$

\begin{tabular}{|c|c|c|c|c|c|}
\hline \multirow{2}{*}{$\begin{array}{l}\text { Trichokompos } \\
\left(\text { ton } \mathrm{ha}^{-1}\right)\end{array}$} & \multicolumn{4}{|c|}{ Pupuk $\mathrm{P}\left(\mathrm{kg} \mathrm{P}_{2} \mathrm{O}_{5} \mathrm{ha}^{-1}\right)$} & \multirow{2}{*}{ Rata-rata } \\
\hline & 0 & 120 & 180 & 240 & \\
\hline \multicolumn{6}{|c|}{--------------- Jumlah umbi per rumpun ---------------- } \\
\hline 0 & $6,00^{\mathrm{a}}$ & $7,33^{a}$ & $7,00^{\mathrm{a}}$ & $9,22^{a}$ & $7,39^{a}$ \\
\hline 5 & $7,89^{a}$ & $7,55^{\mathrm{a}}$ & $7,45^{\mathrm{a}}$ & $8,44^{\mathrm{a}}$ & $7,83^{a}$ \\
\hline 10 & $7,45^{\mathrm{a}}$ & $7,67^{a}$ & $9,22^{a}$ & $9,67^{a}$ & $8,50^{\mathrm{a}}$ \\
\hline 15 & $8,34^{a}$ & $7,56^{\mathrm{a}}$ & $7,22^{a}$ & $7,33^{a}$ & $7,61^{\mathrm{a}}$ \\
\hline Rata-rata & $7,42^{\mathrm{a}}$ & $7,53^{a}$ & $7,72^{\mathrm{a}}$ & $8,67^{a}$ & \\
\hline \multicolumn{6}{|c|}{------------------ Diameter umbi (mm) --------------- } \\
\hline 0 & $7,73^{a}$ & $7,78^{\mathrm{a}}$ & $8,35^{a}$ & $8,80^{\mathrm{a}}$ & $8,17^{\mathrm{b}}$ \\
\hline 5 & $7,43^{a}$ & $8,99^{a}$ & $10,92^{\mathrm{a}}$ & $10,15^{\mathrm{a}}$ & $9,37^{\mathrm{ab}}$ \\
\hline 10 & $8,24^{a}$ & $10,91^{\mathrm{a}}$ & $10,46^{a}$ & $9,44^{\mathrm{a}}$ & $9,76^{a}$ \\
\hline 15 & $8,32^{a}$ & $12,36^{\mathrm{a}}$ & $10,23^{a}$ & $10,14^{\mathrm{a}}$ & $10,26^{\mathrm{a}}$ \\
\hline Rata-rata & $7,93^{\mathrm{b}}$ & $10,01^{a}$ & $9,99^{a}$ & $9,63^{a}$ & \\
\hline \multicolumn{6}{|c|}{---- -------Bobot segar umbi per rumpun (g) --------- } \\
\hline 0 & $2,43^{i}$ & $2,79^{h i}$ & $3,31^{--i}$ & $3,60^{f-i}$ & $3,03^{b}$ \\
\hline 5 & $2,98^{g-i}$ & $4,79^{c-9}$ & $7,08^{\mathrm{ab}}$ & $5,74^{\mathrm{bc}}$ & $5,15^{\mathrm{a}}$ \\
\hline 10 & $3,57^{e-i}$ & $4,92^{\mathrm{c}-\mathrm{f}}$ & $5,55^{\mathrm{b}-\mathrm{d}}$ & $5,45^{b-d}$ & $4,87^{a}$ \\
\hline 15 & $3,89^{d-i}$ & $7,65^{a}$ & $5,21^{\mathrm{c}-\mathrm{e}}$ & $4,44^{\mathrm{c}-\mathrm{h}}$ & $5,30^{a}$ \\
\hline Rata-rata & $3,22^{\mathrm{b}}$ & $5,03^{a}$ & $5,29^{a}$ & $4,81^{\mathrm{a}}$ & \\
\hline \multicolumn{6}{|c|}{------------ Bobot kering tanaman (g) ------------ } \\
\hline 0 & $0,40^{\mathrm{a}}$ & $0,42^{\mathrm{a}}$ & $0,53^{a}$ & $1,45^{\mathrm{a}}$ & $0,71^{a}$ \\
\hline 5 & $0,50^{a}$ & $0,99^{a}$ & $1,61^{a}$ & $1,02^{a}$ & $1,03^{a}$ \\
\hline 10 & $0,55^{a}$ & $1,07^{a}$ & $1,15^{\mathrm{a}}$ & $1,10^{\mathrm{a}}$ & $0,97^{a}$ \\
\hline 15 & $0,63^{a}$ & $1,85^{a}$ & $0,86^{a}$ & $0,88^{a}$ & $1,05^{a}$ \\
\hline Rata-rata & $0,52^{b}$ & $1,08^{a}$ & $1,04^{a}$ & $1,11^{\mathrm{a}}$ & \\
\hline
\end{tabular}

Ket : Angka yang diikuti oleh huruf kecil yang sama pada setiap perlakuan utama dan kombinasinya, tidak berbeda nyata menurut uji jarak berganda Duncan $5 \%$ 
Pemberian trichokompos TKKS terformulasi 5 hingga 15 ton ha ${ }^{-1}$ dan pupuk $\mathrm{P}$ 120 hingga $240 \mathrm{~kg} \mathrm{P}_{2} \mathrm{O}_{5} \mathrm{ha}^{-1}$ dapat meningkatkan diameter umbi. Hal ini disebabkan peningatan hara $P$ dapat meningkatkan pembelahan sel pada umbi sehingga dapat meningkatkan diameter umbi. Menurut Munawar (2011) P berperan dalam pembelahan sel melalui peranan nukleoprotein yang ada dalam inti sel. Pemberian pupuk $\mathrm{P}$ $120 \mathrm{~kg} \mathrm{P}_{2} \mathrm{O}_{5}$ ha $^{-1}$ merupakan diameter umbi yang paling tinggi yaitu $10,01 \mathrm{~mm}$ dan meningkat secara nyata sebesar $26,23 \%$ dibandingkan tanpa pemberian pupuk $\mathrm{P}$. Hal ini disebabkan $\mathrm{P}$ berperan dalam transfer fotosintat dari ke seluruh organ tanaman termasuk umbi. Peningkatan energi dalam bentuk ATP dan ADP sehingga dapat meningkatkan translokasi fotosintat ke bagian umbi sehingga umbi tanaman meningkat. Salisbury dan Ross (1995) menyatakan bahwa fosfor berperan penting dalam metabolisme energi, karena keberadaannya dalam ATP, ADP dan pirofosfat.

Kombinasi trichokompos TKKS terformulasi 15 ton ha-1 dengan pupuk $P 120$ $\mathrm{kg} \mathrm{P}_{2} \mathrm{O}_{5}$ ha $^{-1}$ merupakan bobot segar umbi per rumpun paling tinggi yaitu $7,65 \mathrm{~g}(1,91$ ton ha1) dan meningkat $8,05-214,81 \%$ dibandingkan kombinasi trichokompos TKKS terformulasi dengan pupuk $P$ lainnya. Hal ini dipengaruhi oleh meningkatnya tinggi tanaman dan serapan P. Nilai korelasi antara bobot segar umbi per rumpun dengan tinggi tanaman dan serapan $P$ masing-masing sebesar $r=$ 0,889 dan 0,927 . Peningkatan tinggi tanaman diduga dapat meningkatkan luas permukaan daun, sehingga fotosintesis juga meningkat. Fotosintesis yang meningkat dapat meningkatkan fotosintat yang dapat ditranslokasikan ke umbi tanaman. Translokasi fotosintat semakin cepat karena $P$ berperan sebagai regulator translokasi fotosintat dari organ penghasil ke umbi tanaman sehingga bobot segar umbi per tanaman meningkat.

Pemberian pupuk $\mathrm{P} 120$ sampai 240 $\mathrm{kg}_{2} \mathrm{O}_{5}$ ha $^{-1}$ terlihat cenderung meningkatkan bobot kering tanaman sebesar $100-113,46 \%$ dibadingkan tanpa pemberian pupuk P. Bobot kering tanaman yang paling rendah pada tanpa pemberian pupuk $P$ yaitu $0,52 \mathrm{~g}$. Hal ini disebabkan hara $P$ kurang tersedia untuk pertumbuhan tanaman sehingga dapat menghambat pertumbuhan tanaman seperti pembelahan sel, pengembangan sel dan metabolisme tanaman. Marschner (1986); Havlin et al. (2005) menyatakan kekurangan P sangat menghambat sebagian besar pertumbuhan akar, serapan hara dan air, pembelahan sel dan pengembangan sel, respirasi dan fotosintesis.

\section{Serapan P}

Tabel 5 menunjukkan bahwa pemberian trichokompos TKKS terformulasi 5 sampai 15 ton ha ${ }^{-1}$ meningkatkan serapan $P$ sebesar 76,39\% dibandingkan tanpa trichokompos TKKS terformulasi. Hal ini disebabkan karena pemberian trichokompos TKKS terformulasi dapat meningkatkan ketersediaan hara $\mathrm{P}$. Trichokompos TKKS terformulasi mengandung $2,16 \% \mathrm{P}_{2} \mathrm{O}_{5}$.

Tabel 5. Serapan $\mathrm{P}$ (g $100 \mathrm{~g}^{-1}$ tanaman) tanaman bawang merah pada pemberian trichokompos TKKS terformulasi dan pupuk $\mathrm{P}$

\begin{tabular}{ccccc}
\hline Trichokompos & \multicolumn{4}{c}{ Pupuk P $\left(\mathrm{kg} \mathrm{P}_{2} \mathrm{O}_{5} \mathrm{ha}^{-1}\right)$} \\
\cline { 2 - 5 }$\left(\right.$ ton $\left.\mathrm{ha}^{-1}\right)$ & 0 & 120 & 180 & 240 \\
\hline 0 & 1,276 & 1,432 & 1,584 & 1,978 \\
5 & 1,653 & 2,288 & 3,499 & 2,910 \\
10 & 1,937 & 2,240 & 2,710 & 3,153 \\
15 & 2,445 & 4,603 & 2,617 & 1,395 \\
\hline
\end{tabular}

Ket : tidak dianalisis sidik ragam

Pemberian pupuk $P 120$ sampai 240 $\mathrm{kg}_{2} \mathrm{O}_{5}$ ha $^{-1}$ meningkkan serapan $\mathrm{P} 28,96$ $44,26 \%$ dibandingkan tanpa pupuk P. Hal ini disebabkan pemberian pupuk $P$ dapat meningkatkan ketersediaan hara $P$ sehingga dapat meningkatkan serapan $\mathrm{P}$. Peningkatan pupuk $\mathrm{P} 180$ sampai $240 \mathrm{~kg} \mathrm{P}_{2} \mathrm{O}_{5}$ ha- $^{-1}$ pada Trichokompos TKKS terformulasi 15 ton ha ${ }^{-1}$ terlihat serapan $\mathrm{P}$ cenderung menurun. Hal ini disebabkan kemampuan tanaman dalam menyerap $\mathrm{P}$ secara optimal diperoleh pada kondisi keseimbangan hara. Hasil penelitian Zulfutra (2015) menunjukkan bahwa pemberian $\mathrm{P}$ pada dosis yang lebih tinggi akan mengganggu serapan hara lain seperti hara makro (nitrat dan sulfat) dan mikro (Zn, Mn dan Bo). Kondisi ini menyebabkan pertumbuhan tanaman tidak optimal dan kemampuan tanaman menyerap P menjadi terganggu.

Serapan $P$ yang paling tinggi terlihat pada pemberian trichokompos TKKS terformulasi 15 ton ha ${ }^{-1}$ dan pupuk $P 120 \mathrm{~kg}$ $\mathrm{P}_{2} \mathrm{O}_{5}$ ha $^{-1}$ yaitu $4,603 \mathrm{~g}^{100} \mathrm{~g}^{-1}$ tanaman. Peningkatan seraan $\mathrm{P}$ dapat mempengaruhi tinggi tanaman, laju fotosintesis, diameter umbi, bobot segar umbi dan bobot kering tanaman. Nilai korelasi antara serapan $\mathrm{P}$ dengan tinggi tanaman, laju fotosintesis, 
diameter umbi, bobot segar umbi dan bobot kering tanaman masing-masing $r=0,828$, $0,585, \quad 0,798,0,927$ dan 0,819 . Tinggi tanaman, laju fotosintesis, diameter umbi, bobot segar umbi dan bobot kering tanaman yang meningkat, maka konsentrasi $P$ dalam tanaman dapat berkurang, sehingga tanaman perlu meningkatkan serapa $\mathrm{P}$ secara difusi.

Hasil penelitian secara keseluruhan menunjukkan bahwa tinggi tanaman 16,78 sampai $25,77 \mathrm{~cm}$, jumlah anakan 5,93 - 9,12 anakan, produksi umbi hektar-1 1,91 ton. Hasil tersebut lebih rendah dibandingkan deskripsi tanaman bawang merah varietas Bangkok yaitu tinggi tanaman $29,2-40,8 \mathrm{~cm}$, jumlah anakan 9 - 17 anakan dan produksi umbi hektar ${ }^{-1}$ berkisar 17,6 - 22,3 ton pada tanah mineral. Hal ini disebabkan karena jenis tanahnya berbeda, $\mathrm{pH}$ sangat masam yaitu 3,92 (Tabel 1), sehingga ketersediaan hara, serapan hara rendah dan dapat mengakibatkan pertumbuhan serta produksi bawang merah menjadi rendah. Sutarya dan Grubben (1995) menyatakan pH yang cocok untuk tanaman bawang merah berkisar 5,5 6,5 .

\section{KESIMPULAN DAN SARAN}

\section{Kesimpulan}

1. Pemberian trichokompos TKKS terformulasi 15 ton $\mathrm{ha}^{-1}$ dapat meningkatkan diameter umbi dan bobot segar per rumpun serta respon serapan $\mathrm{P}$ masing-masing sebesar 25,58\%, 74,92\% dan $76,39 \%$. Sedangkan daya hantar $\mathrm{H}_{2} \mathrm{O}$ pada stomata dan laju transpirasi masingmasing sebesar $21,43 \%$ dan $28,79 \%$ dibandingkan tanpa trichokompos TKKS terformulasi.

2. Pemberian pupuk $\mathrm{P} 120 \mathrm{P}_{2} \mathrm{O}_{5}$ ha $^{-1}$ dapat meningkatkan daya hantar $\mathrm{H}_{2} \mathrm{O}$ pada stomata, tinggi tanaman, diameter umbi, bobot segar per rumpun dan serapan $\mathrm{P}$ masing-masing sebesar 7,69\%, 22,25\%, $26,23 \%$, 56,21\% dan $44,26 \%$ dibandingkan tanpa pupuk $P$.

3. Kombinasi trichokompos TKKS terformulasi 15 ton ha-1 dengan pupuk $\mathrm{P}$ $120 \mathrm{P}_{2} \mathrm{O}_{5}$ ha ${ }^{-1}$ merupakan kombinasi perlakuan terbaik, dengan bobot segar per rumpun paling tinggi yaitu $7,65 \mathrm{~g}(1,91$ ton $\mathrm{ha}^{-1}$ ) dan meningkat $214,81 \%$ dibanding tanpa perlakuan trichokompos TKKS terformulasi dan pupuk $P$.

\section{DAFTAR PUSTAKA}

Agus, F. dan I.G.M. Subiksa. 2008. Lahan gambut : Potensi untuk pertanian dan aspek Lingkungan. Balai Penelitian Tanah, Badan Penelitian dan Pengembangan Pertanian.

Badan Pusat Statistik. 2013. Produksi Produktivitas Bawang Merah. Riau dalam angka. Pekanbaru.

Balai Besar Penelitian dan Pengembangan Sumberdaya Lahan Pertanian. 2011. Laporan Tahunan 2011, Konsorsium Penelitian Dan Pengembangan Perubahan Iklim Pada Sektor Pertanian. BBPPSLP. Bogor.

Biyantoro, D., M.V. Purwani dan Muzakky. 2000. Penyerapan Stronsium dan Zirkonium pada Tanah Gambut dengan Zeolit dan Senyawa Humat. In. Prosiding Pertemuan dan Presentasi IImiah Penelitian Dasar IImu Pengetahuan dan Teknologi Nuklir. P3TM-BATAN Yogyakarta. 25 -26 Juli 2000.

Cambell, N.A, J.B. Reece and L.G.Mitchell. 2003. Biologi. Alih Bahasa :L.Rahayu, E.I.M Adil, N Anita, Andri, W.F Wibowo, W.Manalu. Erlangga. Jakarta.

Dwijoseputro, D. 1980. Pengantar Fisiologi Tumbuhan.Gramedia. Jakarta.

Gardner, F.P., R.B. Fearce dan R.L. Mitchell. 1991. Fisiologi Tanaman Budidaya. UI Press. Jakarta.

Hamdani, J.S. 2008. Pertumbuhan dan Hasil Bawang Merah Kultivar Kuning pada Status Hara $P$ Total Tanah dan Dosis Fosfat yang Berbeda. Jurnal Agrikultura, 19 (1) : 42-49.

Havlin, J.L., J.P. Beaton., S.L. Tisdale and W.L. Nelson. 1999. Soil Fertility dan Fertilizer. An Introduction to Nutrient Management. Sixth ed. Prentice Hall. New Jersey.

Idwar, Nelvia dan R. Arianci. 2014. Pengaruh Campuran Kompos Tandan Kosong Kelapa Sawit, Abu Boiler dan Trichoderma Terhadap Pertanaman Kedelai pada Sela Tegakan Kelapa Sawit yang Telah Menghasilkan di Lahan Gambut. Jurnal Teknobiologi, (1) : $21-29$.

Jumini, Y. Sufyati dan N. Fajri. 2010. Pengaruh Pemotongan Umbi Bibit dan Jenis Pupuk Organik Terhadap Pertumbuhan dan Hasil Bawang Merah. Jurnal Floratek, 5 : $164-171$.

Lakitan, B. 2011. Dasar-dasar Fisiologi Tumbuhan. PT. RajaGrafindo Persada. Jakarta.

Marschner, H. 1986. Mineral Nutrition of Higher Plant. Academic Press. London.

Munawar, A. 2011. Kesuburan Tanah dan Nutrisi Tanaman. IPB Press. Bogor. 
Noor, M. 2001. Pertanian Lahan Gambut. Potensi dan Kendala. Kanisius. Yogyakarta.

Puspita, F. 2014. Hasil Analisis Kandungan Hara Trichokompos Tandan Kosong Kelapa Sawit Terformulasi. Fakultas Pertanian Universitas Riau. Pekanbaru.

Ratmini, S. 2012. Karakteristik dan Pengelolaan Lahan Gambut untuk Pengembangan Pertanian. Jurnal Lahan Suboptimal, 1 (2) : $197-206$.

Rosmarkam, A. dan N.W. Yuwono. 2002. IImu Kesuburan Tanah. Kanisius. Yogyakarta.

Salisbury, F.B. dan C.W. Ross. 1995. Fisiologi Tumbuhan. Terjemahan D.R. Lukman dan Sumaryono. Penerbit ITB. Bandung.

Saputro, A.S.H. 2011. Pengaruh Aplikasi Bakteri Fotosintetik Synechococcus Sp.Terhadap Laju Fotosintesis Tanaman Kedelai. Skripsi. Fakultas Pertanian Universitas Jember. Tidak dipublikasikan.

Sasli, I. 2011. Karakterisasi Gambut Dengan Berbagai Bahan Amelioran dan Pengaruhnya Terhadap Sifat Fisik dan Kimia Guna Mendukung Produktivitas Lahan Gambut. Jurnal Agrovigor, 4 (1) : 42-50.

Singh, S. K. and V. R. Reddy. 2014. Combined effects of phosphorus nutrition and elevated carbon dioxide concentration on chlorophyll fluorescence, photosynthesis, and nutrient efficiency of cotton. J. Plant Nutr. Soil Sci. (177) : 892-902.

Stevenson, F.J. 1994. Humus Chemistry.Genesis, Composition, and Reactions.John Wiley and Sons.Inc. New York.

Sutarya, R. dan G. Grubben. 1995. Pedoman Bertanam Sayuran Dataran Rendah. Gadjah Mada University Press. Yogyakarta.

Tan, K.H. 1986. Degredasi Mineral Tanah Oleh Asam Organik. Di dalam Huang, P. M. Dan M. Schnitzer, editor. Kombinasi Mineral Tanah dengan Organik Alami dan Mikroba. Soil. Sci. Soc. Am. J. (17) : 1-40.

Tjitrosomo, S.S. 1990. Botani Umum. PT Angkasa. Bandung.

Tsutsuki, K. dan R. Kondo. 1995. LigninDerived Phenolic Compounds in Different Types of Peat Profiles in Hokkaido. Japan. Soil Sci. and Plant Nutr. 41 (3) : 515 - 527.

Von, C. and Farquhar. 1981. Some relationship between biochemistry of photosynthesis and the gas exchange of leaves. Planta, $153: 376-387$.

Yon, R. Md. 1994. Introduction. p. 1-4. In. : R. Md. Yon $(E d)$. Papaya Fruit Development, Postharvest, Physiology, Handling and Market in ASEAN.

Zulfutra. 2015. Efisiensi Serapan $P$ dan Respon Tanaman Padi Gogo (Oryza sativa L.) terhadap Pemberian Silikat dan Pupuk Fosfat pada Tanah Ultisol. Tesis. Ilmu Pertanian Pascasarjana Universitas Riau. Pekanbaru. 


\section{$\mathbf{J}$

PENGARUH PEMBERIAN PUPUK NT45 DAN PUPUK FOSFAT TERHADAP PERTUMBUHAN DAN HASIL TANAMAN KACANG TANAH

Effect of NT45 and Phosphate Fertilizer on Growth and Yield of Peanut

Nilla Kristina

RESPONS FISIOLOGI, PERTUMBUHAN, PRODUKSI DAN SERAPAN P BAWANG MERAH (Allium ascalonicum L.) TERHADAP PEMBERIAN TRICHOKOMPOS TANDAN KOSONG KELAPA SAWIT (TKKS) TERFORMULASI DAN PUPUK P DI LAHAN GAMBUT

Physiologcal Responses, Growth, Production and P Uptake by Shallots (Allium ascalonicum L.) Against Application of Trichokompos Oil Palm Empty Fruit Bunch (PEFB) Formulated and $P$ Fertilizer on Peatlands

Zaldi Arman, Nelvia, dan Armaini

PENINGKATAN EFISIENSI PUPUK FOSFAT MELALUI APLIKASI MIKORIZA PADA KEDELAI Increasing of Phosphor Efficiency by Mychorriza Application on Soybean

Indah Permanasari, Kartika Dewi, M. Irfan, dan Ahmad Taufiq Arminuddin

KANDUNGAN HARA MAKRO TANAH GAMBUT PADA PEMBERIAN KOMPOS Azolla pinata DENGAN DOSIS BERBEDA DAN PENGARUHNYA TERHADAP PERTUMBUHAN TANAMAN KANGKUNG (Ipomea reptans Poir)

Effect of Azolla pinata Compost with Different Doses for Macro Fertility of Peat Soil and It's Aplication in Plant Growth Kale (Ipomea reptans Poir)

Ervina Aryanti, Hadisa Novlina, dan Robbana Saragih

UJI PESTISIDA NABATI TERHADAP HAMA DAN PENYAKIT TANAMAN

Test of Biopesticide on The Crop Pest and Disease

Mokhamad Irfan 